\title{
Material Interests and Social Norms: Regional Economic Integration in Southeast Asia
}

\author{
HIDETAKA YOSHIMATSL ${ }^{*}$
}

Ever since the early 1990s, the members of the Association of Southcast Asian Nations (ASEAN) have deepened regional cconomic integration, advancing the main programs from the creation of an ASEAN Free Trade Area (AFTA) to the formation of the ASFAN FConomic Community (AHC). This article iclentifies underpinning factors that have qualified ASEAN's such efforts for regional economic integration. In particular, it highlights the evolving perception of material interests due to external environments and socially shared norms as factors influencing $\triangle S E \Lambda N^{\prime s}$ efforts to promote ccomonic integration. I argue that external threats deriving from moves towards stronger regionalism in other parts of the world or the rapid economic growth of the neighloring countrics induced ASEAN members to strengthen their own regional economic cohesion. In addition. ASEA.N's particular see of notsns, such as consensus-building, flexible incrementalism, and informality, were effective in drawing willingness from members with diverse differences to particilare in cooperative programs. However, in the process of shifting from AFTA to the AEC, ASEAN members reconsidered some of these norms by adopting more formal implementation methods, including stronger dispute settement mechanisms.

Kowwrds: ASFAN, neorealisn, const ructivisu, AFTA, ASFAN Economic: Community (AEC)

* Direct all correspondence to Hideraka Yoshimatsu. Professur, Poïirs and International Relarions, Coilegc of Asic Pacific Soudies. Ritsumejkan Asia Paciīic Lniversity 1-1 Jumonjibaru, Beppu. Oita, 8:4-8577

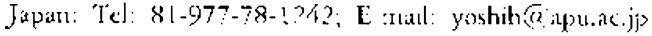




\section{INTRODUCTION}

R cgionalison and econonix: integration have been one of the most outstanding R phenomena in the current international scene. Various regions in the world promote free tralde agreements (FTAs) and other forms of cooperative regional arrangements. Woves rowards regional collaboration initiatives made progress in North America and Eusope since the 1980), but the moves have becn slow in Asia. Southeast Asia was an exception in this context because the region strove to strengthen political cooperation and economic integration since the 1970s.

The five Southeast Asian countries founded the Association of Southeast Asian Nations (ASEAN) in 1967 with an eye at achieving regional peace, scability, and prosperity. ASLAN is a loose, consensus-based organization without any supranational agencies. Partly becausc of this organizational character, major initiatives in promoting economic integration until the 1980) produced modest progress, being plagued by slowtsess, internal division, and meager economic benefits. Since the carly 1990s, economic incegration has been a major policy agenda for ASEAN countrics. In 1992, the members launched an initiative for creating an ASEAN Frec Trade Area (AFTA) by 2008. Afterwards, they accelcratcd the schedule of trade liberalization for AFTA and expanded the scopc of market integration, targeting investmont areas, services sectors and procedures for goods movement. With AtTA virtually in place, ASEAN menbers decided to create a common market with a free flow of goods, services, capital, and labor.

This article cxamines $A S E A N$ 's attempts to devclop economic inte:yration initiatives since the early 1990s, and identify underpinning factors that qualified such attempts. It seeks to address three cuestions. The first is how changes in external environments have influenced ASEAN's efforts to promote regional integration. The second is how ASE.AN's common norms in managing inter-state relations and institution-building influenced the process and progress of ASEAN's regional economic integration. 'The third and more theoretical question is how material interests and socially shared norms have teen transformed into ASEAN's initiatives and policies for achieving stronger economic cohesion.

Before delving into ASLAN's commitrnents to economic integration and cooperation, the following section overviews theoretical literature regarding regional inregration in order to draw an andlytical framework for this study.

\section{MATERIAL INTERFSTS, SOC.IAL NORMS, AND REGIONAL INTEGRATION}

The main interest of this article is why and how Southeast Asian countries have accelerated econonic integration since the early 1990s. Among various perspectives of international relations theory pertinent to regionalism, neo-realist and constructivist 
perspectives seem to be of great relcvance in addressing this question.

According to the neorealist perspective, the relative distribution of power among states in a cortain region provides the most crucial explanatory variable for the development of regionalism. In some cases, the prescnce of a dominant power that has the will and capabilities to supply public goods constitutes the precondirion for the construction of a regional institution (Gilpin 1987; Jake 1988). Under such circumstances, smaller and weaker states that lack the capacity to play a managerial role in the international scene bandwagon the dominant power's behavior. In orher cases, smaller states seek to develop a regional framework as an attempt to balance power in a certain region. 'These states seek to constrain the potentially' disruptive effects deriving from the free exercise of hegemonic power by way of the formation of a regiunal institution (Hurrel 1995, 50-51).

The neorealist approach, which regards the state as a coherent unit and its preforences and beliefs persistent, has strength in its parsimony. This approach is uscful in explaining broad policy outcomes across time in different countrics or gencral trends in the overall international economic system. Yot, it cannot account adequately for why a particular type of policy was adapted within a state or a region. For instance, it provides no explanation of why and how states develop particular preferences regarding regional integration. Ihis problem stems largely from its negligence of dorncstic political factors, such as the role of political leadership or interactions among various political and societal actors.

This article considers external chreats resulting from the evolving regional distribution of power and critical changes in the international system ats the fitst set of variables that condition ASFAN's commiments to regional economic cooperation. However, this article does not posit that changes in international and regional environments lead in a straightrorward way to the state's initiatives and actions. When policymakers and political leaders perceive external threats as critical forces affecting states' material interests, they are likely to formulate and prope: particular initiatives and policies designed to respond to them. Accordingly, I will consider preterences and initiatives of policymakers and political leaders as intervening variables linking external threats with policics for regional integration.

The second theoretical perspective that is pertinent to regional integration is constructivism. The constructivist school, which holds that states' identities and interests are inter-subjectively constructed through norms, rules, and insticutions, contrasts with rationalist theories of incernarional relations. Indeed, all rationalist theorics are opposed to constructivism. For instance, the English school, represented by Hedley Bull and Martin Wight, stressed inter-subjective practices through which international society is constituted and the formation of state identity on culcural bases (Dunne 1995). However, most rationalise theories, including neorealism and neoliberalism, assume that the state's identity can be hold constant, and its interests are stablc and exogenous to interaction (Powell 1994).

Constrictivisis claim that the international structure and the state as an agent 
within it are mutually constitutive. Whereas the international structurc constrains the state, the state maintains the legitimacy and stability of the international structure through its self-understanding and international behavior (Hasenclever, Mayer and Rittberge 1997, 188). According to the constructivist perspective, inrernational relations are shaped not just by material forces such as power and wealth, but also by the interplay of inter-subjective factors (Wendt 1992). Elements such as identity, ideas, and norms do matter in constructing the international system socially. Therefore, regional integration emerges and develops when collective identity or regional awareness is socially constructed among the states in a ccrtain region.

Some scholars criticize that the constructivist arguments about the importance of identity or ideas risk being too empirically thin and analytically malleable. Identity and ideas are ternous concepts that are less likely to link with distinctive testable hypotheses (Moravesik 1999, 670-7\%). It is difficult to measurc precisely to what extent identity or ideas influences actors' preferences and behavior. Morcover, constructivists have not shown what agents (states) or what kinds of structures will be important in analyzing a particular phenomenon of international politics (Haggard 1991 , 114-15).

Given the above criticisms, it is risky to regard the constructivist perspective as the single variable to explain inter-state relations or state behavior. Yer, it would be useful to consider common norms and identity as supplementary factors explaining inter-state relations in a region where shared norms and identity have played a distinctive role. In this context, the constructivist perspective matters in cvaluating ASEAN's commicments to regionalism because $\triangle$ SEAN members have developed, through diplomatic interactions and practices, the so-called " $\triangle S E A N$ way". The ASEAN way is a set of norms that include the non-interference principle, informal consultation, pragmatic expediency, consensus-building, and flexible incrementalism (Acharya 1997, 329-33; Iin 2003, 20-22). The ASEAN way, characterized by the rejection of legalism and its emphasis on informal tlexibility and consensus-building, is not compatible with the neoliberal paradigm, which stresses universalism on a legal and institurional basis.

'The ASEAN way has often enabled the states to procluce the smooth formulation of cooperation because it can draw political willingness by increasing "the "lcvel of confort' among the participants and create a flexible decision-making environment which would allow room for mutual accommodation aniongst national bargaining positions" (Acharya 1998, 58). At the same time, rhe $\Lambda$ SEAN way has been thought to impede the development of substantial cooperation because it tends to filter out or exclude contentious issues from the formal multilateral agenda, and to bay more time in reaching a final agreement (Thambipillai and Saravanmuttu 1985).

A noreworthy question is how the ASEAN way has qualified ASEAN's commitments to regional economic integration in the evolving regional and global environments. Since the ASEAN way is a set of norms that provides standard guidelines for behavior, it incorporates the character of innutability or durability. Ilowever, dynamic 
evolutions might have gradually changed the application of norms at first, and then transformed the norms themsclves. Particularly important issues are in what ways changes in norons took place and how such changes can be confirmed. This article highlights preferences of $A S E \Lambda N^{-}$'s policymakers for major norms in the $A S E A N$ way, and examines preference changes.

Thus, this article explores the causes and major characteristics of ASE AN's initiatives for stronger economic integration since the early $1990 \mathrm{~s}$ by combining the neo-realist and constructivist perspectives. The independent variables include: 1) material interests that ASEAN states seek to secure in the evolving international and regional settings; and 2) a set of norms that ASEAN members have socially accepted in their diplomatic relations. The dependent variables are $A S E A N ' s$ initiatives in and actions for promoting closer economic integration through market liberalization. The intervening variables that link the independent and dependent variables are preferences of policymakers and political leaders.

In the following section, I will trace the development process of ASFAN's commitments to stronger and closer regional integration. I employ a process-tracing approach to illustrate how exrernal threats and regionally shared norms influence the progress of market libcralization and regional integration at different juncrures. The process is divided into two parts: 1) the 1990s, when ASEAN members made efforts to AFTA-based market integration; and 2) the new millennium, when they launched new programs to create a common market.

\section{INITIATIVES FOR DEEPER AND LARGER INTEGRATIION IN THE $1990 \mathrm{~S}$}

\section{The Initiation of AFTA}

Economic cooperation was long given low priority after ASFAN was founded in 1967. Although preferential trade arrangements and industrial complementation schemes were launched in the late 1970s and early 1980s, they produced meager outconses.' Judging from past achievement, a milestone in ASEAN's attempt to promote conomic cooperation was AFTA. At the fourth summit in January 1992. ASEAN leaders agreed to establish a free trade area by 2008 by signing the Framework Agrcement on Fohancing ASEAN Economic Cooperation. Under the Common Effective Preferential Tariff (CFPT) Scheme, the main mechanism for achieving AFTA, existing cariffs on manufactured goods and processed agricultural products would lower to between 0 to $5 \%$ and quantitarive restrictions and other non-tariff barriers would be eliminated. ASEAN leaders also agreed to set up the AliTA Council, a ministerial body to supcrvise, coordinate and review the implementation of CEPT.

A plan to establish a free tradc area among ASEAN mernbers was first articulated 
by Thai Prime Minister Anand Panyarachun. Anand revealed this idea when Singaporean Prime Minister Goh Chok Tong visited Thailand in Junc 1991 (Stubbs $2000,30 / 4$ ). The Thai govermment pushed forward this idea at various opportunities, including an ASEAN Ministerial Mecting (AMM) in July 1991 and the twenty-third ASEAN Economic: Ministerial Meeting (AEM) in October of the same year. The idea to form AFTA was swiftly approved together with CEPT.

Importantly, an idca to create a free trade arca under the ASEAN framework was considered from the early 1980s. ASEAN ministers commissioned a taskforce to review and give recommendations on economic cooperation in ASFAN (Nagai 2002, 5). Headed by Anand, the taskforce issued a report in 1982, which referred to the formation of a free trade arca (Yamakage $1997,206-7$ ). At the 1992 summit, Anand made cfforts to promote AFTA, proposing that Thailand would reduce all tariffs on imports from ASEAN countries to a maximum of $30 \%$ by the beginning of 1993 (Akrasanee and Sufol 1992, 43-14). Anand originally presented a ten-year timeframe for the realization of AFIA, but the time frame was extended to fiftecn years after taking account objections from Indonesia and the Philippines (Nesaduarai 2003, 54). Thus, not only did Anand and the Thai government initiate AFTA, they also atcempted to push forward its accelerated realization.

Compared with cconomic integration initiatives of the past, the AFTA proposal was realized snoothly. Why did ASEAN members agrec to form AFTA without serious objections or reservations? Several explanations have been presented. First, AFl'A was utilized to overshadow the East Asian Economic Grouping (EAEG). In December 1990, Malaysian Prime Minister Mahathir proposed the EAEG concept when Chinese Primer Li Pang visited Kuala Lumpur. The group comprises only Asian members, including ASE $A N$ countries, China, Japan, and South Korea, and excludes the United States and Australia. $\triangle S E A N$ members, heavily rdiant on the LS and European markers for their exports, were reluctant to approve the closed concept of the EAEG. The AFTA and CEPT wese presented as alternatives to the FAEG (Yamakage 1997, 143; Sato 2003, 116-17). Second, AFTA was an appropriate way of maintaining the raison d'etre of ASEAN, which needed a renewed sense of purpose and direction in the early 1990 s. The end of the Cold War and Indochina conflicts reduced the strategic importance of the association as an ally to the capitalist bloc and undermined the utility of the association to its own members. AFIA was regarded as a significant instrument to maintain ASEAN's idencity as a purposeful and viable organizarion (Ravenbill 1995, 854; Becson 2002, 190).

In addition to the ahove reasons, a critical factor prompting $\Lambda \mathrm{T} T A$ initiatives was the thrat of isolation duc to rising moves towards regionalism in major parts of the world. Given that the General Agreement on Tariffs and Trade (GATT) Uruguay Round was facing a deadlock, major Europcan countries and United States intensified rerional initiatives. Europcan countries werc deepening integrative programs by forming the European Single Market in 1942. The Linited States already 
agreed on the US Canada FTA in 1987 and began negoriations over the formation of a comprchensive FTA with Mexico in June 1990. The North American Free Trade Arca (NAFTA) of the United States, Canada, and Mexico was signed in August 1992. NAFTA's formation was expected to lead to trade and investment diversion from ASEAN to Mexico (Muto 1997, 38). ASEAN' members feared that moves towards regionalism would lead to more protectionist and inward-looking trade measures, threatening their traditional exporc markets as well as their position as major investment recipients. AFTA would create an integrated regional market of over 400 million people, a combined purchasing power of over US\$400 billion growing at 6-8\% annually and a wide range of resource endowments and skills (Chia 1998, 218).

AFTA promoters strongly perceived the threat imposed by increasing regionalism. Anand stressed the need of AFTA in reference to regionalism in other areas as follows: given that integration and protectionist moves are accelerating in Europc, America, and Japan, where ASEAN countries depended on trade and investment, it is neccssary to integrate the internal market of six countries in order to win in fierce competition for acquiring foreign capital. 2 Singaporean Primc Minister Goh also commented that "unloss ASEAN" can match the other regions in attractiveness both as a base for investments and as a market for their products, investments by multinational companies are likely to flow away from our part of the world to the S[ingle? E[uropean] M[arket] and NAFIA."

The AFIA initiation dearly followed the ASEAN way: "agree first, talk after." The AFTA agreement was reached within ten nonths after its initial proposal. The AFT $A$ document of fiftecn pages contrasts sharply with other regional FTAs, such as NAFTA's 1000-plus-page agreement (Ravenhill 1995, 859). The CEPT simply provided some guidelines to tariff cuts and allowed for enormous flexibilicy in the implementation process. Although some members with fragsile state capacities were reluctant to join AFTA, the vaguely stipulated agrecments made all members, including reluctant ones, feel comtortable joining the progran. Informality allowed AFTA to move forward at a pace with which all governments felt comforable, while flexibility cnabled member governments to seek ways to deal with domestic opposition to AFTA (Stubbs 2000, 312-4).

\section{The Acceleration of AFTA}

The agreement to create AFTA was rached within ton months afrer its initial propusal. Accordingly, the agreement did not include details for implementation, and backsliding moves immediately ennerged. At the third AFTA Council in December 1992, each member state revealed the CEPT plan. But there were variations in the time to begin trade liberalization: Singapore from January 1993; Malaysia from 1993; Bunei fron 199/; 'Thailated and Indonesia from 1995; and the Philippines from 1996 (Yamakige 1997, 199). 'The diversity in implementation becance apparent 
only one yar after the conclusion of the agreement.

However, ASEAN members made bold decisions in 199' an accelerating MFT $\Lambda$. At the twenty-sixth AEM in September 1994, the Ministers decided to shorten the timeframe for frec trade completion, from fifteen to ten years, to extend sectoral coverage to unprocessed agricultural goods, and to climinate the temporary cxclusion list within five years, instead of a review at the end of eight years. As a consequence, AFTA would be realized by 2003 instead of 2008 , and the whole agricultural sector would automatically be included in the CEPT schene. At the fifth summit in December 1995, ASEAX leadcrs agreed to further accelerate progress towards the actualization of AFTA before the target date of year 2003. Member countrics would maximize the number of items with tariffs reduced to $0-5 \%$ and expand the number of products with tariffs reduced to $0 \%$ by the year 2000 . Iseaders also agreed to remove all quantitative restrictions and non-tariff barriers with the process beginning in January 1996.

Several governments promoted the new initatives. The Thai grovernment pushed the 1994 achicvement forward. When Deputy Prime Minister Supachai Panitchpakdi attended a Pacific Economic Council Conference (PECC) meeting in Match 1994, he conthusiastically demanded the early rualization of AFTA, proposing to shorten its schedule for tariff reductions from fifteen to ten years and to put agricultural goods and petrochemicals on the list for tariff cuts. ${ }^{4}$ In August 1994. Supachai confirmed Thailand's basic position at a meeting of economic ministers in the cabinet, that the government would encouragc $\triangle F T A$ implementation and economic cooperation among ASF:AN members in areas such as the services sectors and unprocessed agricultural products (Nagai 2002, 6-7). These proposals were brought to an $\Lambda E M$ in September 1994.

The decision to shorten AFTA's timeframe only a few years after the initial decision was itufluenced by changes in external environments. The GATT Uruguay Round was completed in December 1993, and all ASEA $i$ nembers ratified the Uruguay Round Agreements. Moreover, the Asia-Pacific Economic Cooperation (APEC) gained momentum by holding its summit meetings in Seattle in November 1993 and in Bugor one year later. In Bogor, APLC members agreed to accomplish pan-regional free trade by the year 2010 for developed country inembers and 2020 for developing country members. APl:'s development raised the sense of crisis among ASEAN policymakers, both because they felt more vulnerable to pressure from larger APEC countrics and hecause they feared that ASEAN itself would be overshadowed or even pre-empted by the larger grouping (Lim 1996, 22).

Several policymakers explicitly expressed concerns deriving from external changes. For instance, at the fifth ASEAN summit in December 1995, Singaporcan Prime Minister Gol stated, "Under the Uruguay Round, countries have agreed to bind their tariffs for both industrial and agriculture goods and to reduce them over next five to ten years. The $\mathrm{EL}$ common market is embjacing eastern and central Europe, and goods ate traded within the LU tariff-frece." 


\section{Difficulties in Consolidating Integration Initiatives}

While ASFAN's policymakers were serious about promoting market integration, actual processes for this objective were not steady. 'Two incidents gave vital challenges to AFTA's credibility. The first was disputes over agricultural products between Indonesia and 'Thailand. In early 1995, the lndonesian government transferted iifteen unprocessed agricultural products from the Temporary Exclusion List to the Sensitive List under CEPT. I'his move provoked a sharp response from Thailand, a major exporter, and its govermment threatened to withdraw forty-four agricultural products from CEPT in retiliation. This incident ended with a compromise: ASEAN members agrecd to allow Indonesia to finalize CEPT liberalization of agricultural products until 2010 (Nesadurai 2003, 155). Member governments artempted to tighten rules and procedures to avoid loopholes in the treatment of agricultural products. In Scprember 1999, the Prutocol on Sensitive and Highly Sensitive Pruducts was adopted.

The second incident occurred over the treatment of auto-related products. At an AEM in May 2000, Malaysia requested for a delay until 2005 in transferring 218 tariff lines of complete knocked-down (CKD) and complete built-up (CBU) automobilc products from its Iempotary Lxclusion List to the Inclusion I.ist. Originally, Malaysia was to start the transfer. in 2000 and in effect bring down the import tariffs of automobile-relared products to $20 \%$ or less, and gradually to $0-5 \%$ by the ycar 2003 . Thailand, the major automobile producer country in Southeast Asia, opposed Malaysia's policy, threatening to delay import tariff reduction on palm oils, rhe main Malaysian export item. This issue was settled at the thirty-second AFM meeting in November 2000 with the adoption of the Protocol Regarding the Interpretation of the CEPT Scheme Temporary Exclusion List."

The above two incidents indicated ASEAN's fallure to secure the original commitments to market liberalization. The non-binding, flexible character of $A F T A$ allowed member states to deviate from original commitments when was forced to protect the interests of major domestic industries. Other members were unable to block such moves, being forced to adopt the clownward revision of commitments from rhose previously agreed upon.

The 1992 CEPT Agrcement did not include a mechanism for dispute setrlement. Ir only stipulated in Article 8 that member states should try to amicably settle any disputes arising from AFTA implementation through consultation. In April 1995. "Thatiland proposed a dispute-settlement mechanism, and the Protocol on Dispute Settlement Mechanism (DS.M) was signed at an AEM in November 1996. According to the protocol, when no amicalsle setelenerne could be reached through bilateral consultation and negotiations, a dispute can be referred to a senior officials meeting (SEOM), which will convenc a panel of experts to assist the SFOM to make a ruling. Importantly, decisions on a dispute in the pancl and in the SEOM will be taken on the basis of a simple majority. If the ruling by the SEOM is found to be unsatisfactory, a party to the dispute can appeal to the AEM, which 
would also make decisions based on a single majority. The AFM's decision on the appeal shall be final and binding (A8 of the Protocol). The use of the single majority vore was a departure from the ASEA.N way of making decision by conscnsus (Kehler 2000, 567).

Although the DSM had a significant implication in ASEAN's decision-making, it did not work effectivcly. The mechanism did not provide sufficient regulations to implement a final ruling. A member state that fails to comply with the ruling faces no punitive measures, but shall enter into negotiations with any party involved the dispute settlement procedures with a view to developing mutually acceptable compensation (I lund 2002, 108). Furthermore, member countrics did not heavily utilize the DSM. ASFAN members gave more respect to conflict avoidance than conflict resolution.

The agreement's likewarm implementation was seen in the liberalization of the services sector. In December 1995, ASEAN leaders signed the ASEAN Framework Agreement on Services (AFAS). The AFAS aimed at eliminating restrictions to trade in services so as to improve the efficiency and competitiveness of services suppliers in the region. Under the AFAS, initial negotiations focused on five arcas: 1) financial services; 2) transport; 3) telecommunications; 4) tourism; and 5) professional busincess services. However, an analysis of the sectors indicates that little progress was achicved during the first several years of negotiations (Stephenson and Nikomborirak 2001; Rajan and $\operatorname{Sen} 2002$ ). The causes of this lay in such factors as the lack of tight negotiation frameworks and weak political will to opern up the services matket (Stephenson and Nikomborirak 2001, 7-10).

In the second half of the $1990 \mathrm{~s}$, complicated moves were seen with regard to the AFTA implementation and rclevant policies. Some countries keen to protect the domestic industry's interests made reservations in market liberalization under the CEP'I schedule, and the flexibility of the agreement allowed for such a loophule. At the same time, given the growing needs of more efficient and tight policy formation and implementation, ASEAN leaders adopted new agreenents and mechanisms that had the potential to accelerate market integration by revising some of the basic notmis of the ASEAN way. Yer, these agreements and mechanisms were tot forcefully implemented and had meager effects on the actual integration process. This implies that excernal pressure gradually changed ASE $A N$ laders' perception of ASEAN norms, but practical moves did not follow such changes.

\section{FURTHER COMMITMENTS TO ECONOMIC INTEGRATION IN TIIE NEW MILLENNIUM}

\section{New Initiatives for Stronger Integration and ASEAN Norms}

In the new millernium, ASEAN members sought to further advance the integration 
process by adopting new initiatives. At the fourth informal summit in November 2000, ASEAN leaders endorsed the Initiative for ASEAN Integration (IAI). This initiative aimed at assisting new ASEAN members (Cambodia, Laos, Myanmar, and Victnant) to keep up with former members in regional integration efforts and narrow the development divide between the two groups. In order to implement this initiative, ASEAN leaders approved the IAI Work Plan for Narrowing the Development Gap within ASEAN at the eighth summit in Novembar 2002. Concrete projects under the six-year Wurk Plan focused on four major arcas: 1) development in infrastructure; 2) humran resources development; 3) information and communication technolugy; and 4) capacity-building for regional cconomic integration."

The IAI was crucial in enabling the steady progress of marker liberalization and regional integration. There was a large gap herween old and new ASEAN members. In 2003, per capita gross domstic product (GDP) of the richest, Singapore (LS\$20,987), was 117 times larger than the poorest, Myanmar (US\$179). The gap in econumic development naturally affected the progress of market liberalization. W'bile old members achicved $99.5 \%$ of the $0-5 \%$ tariff range by 2004 , the four new members reached $65.7 \%$ ?

Noteworthy moves were secn in trade liberalization in services. In 2002, ASEAN members decided to adopt two measures in service trade liberalization. The first was the modified common sub-sector approach. Inder this approach, a particular sub-scctor would be identificd as a common sub-sector if three or more countries make commitments in this sector under the General Agreement on Trade in Services (GATS) or che AFAS. The identified common sub-sector would be subject to the $r$ r.moval of all limitations for modes onc (cross-border supply) and two (consumption abroad) and to progressive liberalization for mode three (commercial presence) and mode four (presence of natural person). 'The second was the application of the ASEAN-x formula. Under this formula, two or more countries may conduct negotiations and ayrec to liberalize trade in scrvices for specific sectors, while others could accede at a later stage. A1 the thirty-fourth AEM meering in September 2002, the ministers endorsed the set of parameters ro guide the implementation of the ASEAN-x formula under the AFAS, and signed the Protocol to Amend the AFAS, enabling the application of the ASEAN-x formula to members' service commitments.

A more ambitions initiative for regional economic integration was launched in 2003. At the ninth summic at Bali in October 2003, ASEAN leaders agreed to establish an ASEAN Economic Community (AEC). The objective of the AEC was to set up a single market and production base with a free flow of goods, services, investment, capital, and skilled labor. Singaporean Primc Minister Goh first articulated the formation of the $A E C$ at the previous summit. Aftcrwards, ASLAN members asked the Institure of Southeast Asian Studies (ISEAS) to produce a concept paper on the $A E C$, and exchanged views with the $\triangle S E A N$ Institute of Strategic and International Studies (ASEAN-ISIS) over the paper. ${ }^{11}$ The AEM set up the High level Task Force (HI.TF) on ASEAN Fconomic Integracion, the 
latter's mission to explore the AEC concept and other ideas on intensifying ASE.AN economic cooperation and deepening market integration.

At the second informal summit in December 1997, ASEAN laders endorsed the ASEAN Vision 2020. But this vision only aimed to establish an ASEAN economic region. 'ithe AEC intended to transform ASEAN into a common market by 2020 alung the lines of the European Economic Community. In order to accelerate the liberalization process, ASEAN members decided on the fast track eleven priority sectors where a single market would be formed by $2010.1^{2}$ Measures for these sectors included zero tariffs, rcmoval of non-tariff barricrs, faster harmonication of product standards, mutual recognition of est reports and certification, faster customs clearance, and simplified customs procedures.

ASEAN members strengthened the AFC further in the following year. In November 2004 at the tenth summit, ASEAN leaders launched the Vientiane Action Program (VAP). The VAP was the second mid-term (2005-2010) plan, succeeding the Hanoi Plan of Action that ended in 2004.13 The program contained clearer groals and stratcgies for realizing the ALC: incegration completion in the eleven priority scctors before 2010; tariff elimination for products by 2010 for old ASEAN members and 2015 for new ASEAN members.

The new initiatives launched afeer 2000 were accompanied by the transformation of ASEAN norms. This was the case in service trade libcralization. Both the modified common sub-sector approach and the $\Lambda$ SEA $Y^{\prime}-x$ formula implied a departure from the consensus principle. The former enabled some nembers to promote liberalization in sectors that were more rapidly growing and less affected by national interests. The latter allowed ready and willing members to expand and deepen negoriations in all sectors. Under these new approaches, joint collaboration in an undertaking could proceed without full consensus, but begin with a coalition of willing countries until the others are able to join. The approaches had the potential of enhancing $\Lambda S E \Lambda N^{-1}$ s cfficiency by avorting the possibility of inaction dele to the absence of consensus. Morcover, the demonstration effects were expected to encourage non-participant members to join a successful underaking (Hernande\% 200I, 117).

The AEC and relevant initiarives wore accompanicel by proposals that departed from ASEAN norms. First, the AEC contained concrete and institutionalized measures designed to form an economic communicy. As alseady explained, there was a tendency for ASEAN members to decide on the framework agreement first and then substantiate the content at a later stage. This increnental and flexible approach rook time in conceptualizing the substance and transferring to practical actions. As for the AEC, ASEAN leaders immediately commissioned the ISEAS to formulate a concept paper to achieve the objective, and the paper contained concrete, substantial measures.

Second, ASEAN members prepared more formal and institutionalized mechanisms to ensure the proper inplementation of all economic agreements and the expeditious resolution of any disputes. At the thirty-sixth AEM in September 2004, the ministers 
agreed to set up three new mechanisms. The first was a legal unit within the ASEAN Sccretariat. This unit aimed to provide governments with legal advice on trade disputes. 'Ihe second was the ASEAN Consultation to Solve Trade and Investment Issues (AC'I). The AC'I was a network of government focal points where private sector complaints and operational problems in implementation could be channelled for specdy resolution. The third was the ASEAN Compliance Body (ACB). The body performs a quasi-judicial function by reviewing a trade dispure and issuing a judgetment that is not legally binding, but can be used to take steps to sctcle the disputes. Importantly, these mechanisms were modelled from the FIj and World Trade Organization (WTO). Whereas the AC.T initated the example of the EL Solvit mechanism, the ACB was modelled after the WTO Textile Monitoring Body.

The ministers also agreed to replace the 1996 Protocol on DSM with the ASEAN Protocol on Enhanced Dispute Settlement Mechanism. The new protocol strengthened the DSM system in various ways. First, the new protocol reduced ambiguity. While the old protocol had only twelve articles with short passages, the new protocol had twenty-one atticles with substantial passages. Second, the new protocol stipulated the establishment of the Appetlate Body. The hody, comprised of independent and experienced professionals, makes judgements on a legal basis. Third, the new protocol provided procedures for the surveillance of implementation. While the new protocol still admitred strong involvenent of SEOM, an inter-governmental body, it established a tighter dispute settlement mechanism following the WTO's Dispute Settlement Linderstanding.

Third, the AEC contained further measures to draw away from consersus-driven decision-making. In formulating the AEC, ASEAN leaders agreed on the adoption of a "2+x" approach at the $2003 \mathrm{Bali}$ suminit. In the $2+x$ approach, two able countries are allowed to liberalize certain secors bilaterally without pursuing an agreenent from all enembers. Those who are not ready will be able to join at the latter stage. Singaporean Prime Minister Goh explained the implications of the adoption as follows: "in the past, nothing moves unless all ten countries agreed to an idea. So now we turned it around to say "two plus $x$." So any two countries that have an idea can prestiat their idea to the ASEAN leaders and the two countries alone can carry on, but they must be open to other members who wish to sign up on a reciprocal basis. 1 " Linder this approach, Singapore and Thailand liberalized air cargo service sectors, and Brluei, Cambodia, and the Philippincs asked to join in this schenos.

'Thus, in the new millennium, $\triangle S E A N$ members commited to further rarket integration by launching new initiatives. The initiatives designed to achicve an effecrive and deepened integration, accompanied by the modification of ASEAN norms such as conscnsus-building and informal incrementalism. Members sought to overcome the stalemare in the late 1990 s by revising the application of ASEAN norms. 


\section{Market Integration and Fxternal Threats}

Why did ASEAN members launch new programs for market integration in the new millennium? Integration neasures were reactions to changes in the surrounding cnvironment, relations witl China and India in particular. ASEAN's economic position vis-a-vis China declined furcher in the new millennium, and China has been the primary recipient of foreign dircct investment (FDI) annong devcloping countries since 1992. FDI into ASEAN increatsed from US315 billion in 2002 to USS19 billion in 2003, but the 2003 figure was still less than $40 \%$ of Chinas corresponding figure of US\$54 billion (UNCTAD 2004, 50). There was a growing perception that China's rapidly expanding economy would further divert FDI inflows away from ASEAN. In addition, China's economic presence gradually increased in the Southcast Asian market. China expanded exports of relatively high-end products to Southeast Asian countries, for instance, Chinesc motorbikes and clectronic products, including refrigerators, washing machines, and air-conditioners, have found their way into Indonesia, Victnam, and the Philippines. Some Chinese electronics firms began local production in Indoncsia and Victom. While 'I'Cl started operations of a TV plant in Vietnam in 1999, Changhong and Konka opened a IV plant in Indonesia in 2000 (Maruya and $\mathrm{Abc} 2002,20$ ). In addition to China, another neighboring country has emerged as a serious rival to ASEAN. India raiscd its presence in the world econony by developing global oursourcing linkages in information and computer technology. Major information technology companies such as General Electric, Microsoft, Intel, and Cisco expanded investment in the country. The pool of English-speaking human resources for computer software is expected to raise the country's economic potential.

Confronted with China and India's growing influence, some ASEAN leaders deepened their anxiety about the relative decline of Southeast $A$ sia as a growth pole in Asia. This concorn was revealed in their desire for accelerated internal market integration. At an ALM in September 2003, the ministers agreed on rlo 2020 timeframe for the AEC. completion, accepting some countries' reservarions about opening the market roo hastily. ${ }^{15}$ Thai Prime Minister Thaksin Shinawatra and Singapurean Prime Minister Goh considered that the 2020 might he too late, hoping to sce an earlier completion date. At the 2003 Bali summit, Thaksin argued that the AEC should be formed by 2012 to prevent such a goal becoming obsolete. Ile feared that if ASEAN's integration moved slower than that datc, outside forces would undermine the internal integration process as AStAN would forge F'I'As with China by 2010, lndia by 2011, and Japan by 2012. 'Thaksin stated, "here's acute awareness new that if you don't hang together, you're going to hang scparately, given the competition from China and, later on, India". It

While China's looming economic cxparision posed a serious challenge to ASEAN members, the growing Chinese market provided them with chances for business expansion. In order to change China's economir growth from threas to opportunity, 
ASE AN members needed to improve the competitiveress of local industries and firms. Before the launching of the $\mathrm{AEC}$, the $\mathrm{AEM}$ commissioned a consultant company, McKinsey and Company, ro conduct an ASEAN Competitiveness Siudy in 2001 . The study examines and identifies measures for maximizing specific industrial potential, creating opportunities for faster growth, lindertaking regional initiatives, and enabling measures to boost international trade and investment. 'The AVC contained metasures for crade facilitation in addicion to trade liberalization. Trade facilitation measures, such as faster customs dearance and the harmonization of product standards and echnical regulations, werc indispensable in taking advantage of regional diversities to further specialize, and realizing economies of scale through reduced transaction costs. ASE NN menubers hoped to promote commercial cosoperation and synergistic integration among loxal firms, some of which would develop the potential of becoming regional multinational entcrprises. Firms with larges economies of scale on their home ground (Southeast Asia) were expected to advance into the Chinese market and compete outright with rival firms there.

Importandy, $A S E N N^{-}$governments attempted to strengthen linkages with the business community in order to prop up improvement in the competitiveness of local firms and industrics. In 2000, the ASEAN Secretariat began $t$ issue a bulletin, Busineis ASEAN. 'This quarterly bulketin ains to deliver information about ASEAN's policy and up-to-date business activities in Southeast $A$ sia to business circles. 'The seventh summit in 2001 approved an intiative to lantoh the $A S E A N$ Business Advisory Council (ASFAN-BAC) and the ABAC hed the inaugural meeting in April 2005. The council, whose thirty members were nominated by their representative govermments, was expected ro provice ASFAN leaders with advice on the future direction of ASEAN's conomic integration and industrial competitiveness (Nesadurai 2004, 14-17). The ASEAN-BAC delivers requests and preferences of the private sector to the policymaking process by publishing a report directly reached to $A S E A N$ leaders, as well as by organizing the ammal $A S L^{\prime} A N^{\prime}$ Business and Investment Summit back to back with the $\triangle \mathrm{SEAN}$ lcaders' summit. ldcas and requests from the private sector are incorporated inco concrete programs. For instance, in deciding on priority in integration scctors for the $\mathrm{AEC}$, eacl government convened consultrative mectings with industrial representatives. ${ }^{7}$ Many $A E C$ initiatives were formulated with due consideration to business intercsts.

Vesidurai (2003) argues that some ASEAN members pursued the "developmental. regionalism" in AFTA development by giving privileges to local firms. ASEAN members still chased developmental regionalism in the now millennium, but the manner in achieving this objective changed. 'Ihat of the $1990 \mathrm{~s}$ was inward hoking, protecting the domestic marke from foreign competition. While that of the new millennium becanne outward-uriented, pursuing the formation of regional economics of scale to enable local firms to become enultinational. To this end, member governments triced to strengthen institutional linkages with the private sector and paid due consideration to their interests and regnests. 
In brief, external threats deriving from the rapid growth of the Chinesc and Indian conomics induced ASEAN policymakers to promote further regional market integration. They sought to compere with China and India by fostering local firms with an ability to become multinational. To to this, ASEAN governments tightened linkages with the business sector and sought to reflect its interests and demands in actual integration policies.

\section{CONCLUSION}

This article examined the coolution of ASEAV's attempts to promote closer cconomic integration since the early 1990s. Member counrries advanced formal integration programs from the AFTA initiative in 1992 to the AFC. in 2003. In this process, perceived external threats played a pivotal role in prompting ASEAN countries to have positive stances regarding economic integration. At first, threats from moves in broad areas, such as intensive moves towards regionalism in North America and Europe and market liberalization under APEC, induced ASEAN countries to advance the formation of a regional free trade area.

In the new millennium, ASEAN countries were confronted with direct threats from neighboring countries. In particular, they felt serious theats from China's rapid economic growth. Not only did China attract huge FDI, but its products and firms also advanced into the Southeast Asian market. In order to respond ro threars from the neightoring countries, $\Lambda S E \Lambda N$ members pushed forward deeper and tighter regional linkages through the IAI and AEC. They aimed to foster capable local firms with the potential of becoming multinational enterprises. Thus, the securing of material interests from external economic threats was an underpinning force in $\mathrm{ASEAN}^{-1}$ s efforts to promote market integrarion.

ASEAN members, through diplomaric practices, developed a particular set of norms that includes consensus-building, flexible incrementalism, and informality. While these norms were effective in drawing willingness from a diverse member group to participate in cooperative programs, the changing environment forced ASEAN members to reconsider some of them. Through the second half of the 1900s, $\triangle \mathrm{SE} \Lambda \mathrm{N}$ countries sought to shift from loose to tight cooperation based on more formal mechanisms. To this end, they adopted the DSM. They also promoted less undiffercntiated liberalization by broadening the scope of liberalization and imposing strict timeframes. However, these commitments did not produce expccted results. The DSM was not heavily utilized and action plans for tighter enforcement were not formulated in many areas. Furthermore, a flexible process was adopted in the liberalization process as seen by the revision of original commimments.

In the new millennium, ASEAN members launched new initiatives for promoting market integration. In particular, the AEC aimed to create a single market characterixed by a free flow of goods, strvices, and skilled labor. ASEAN members departed 
from the basic norms of the ASTAN way in order to implement progtanns for creating the integrative market more quickly and effectively. They sought to promote integration among members who were ready and willing, thus transforming consensus-based decision-making. They also adopted more formal, tighter implementation methuds, including stronger dispute settlement mechanisms. Thus, external economic threats forced major political leaders to make more decisive efforts to promote market integration. In this process, they transformed the perception of shared norms that had led ASEAN's diplomatic rclations.

It is useful to apply some implications of this study to regional cooperation in the broader East Asia region. In East Asia, external economic threats became an impetus in promoting regional cooperation. The development of the cooperative APT framework was triggered by the Asian financial crisis in 1997-98. While the region's major economies recovered from the crisis, they are facing the threats (and opportunities) of globalization. Discovering how to cope with globalization will be key in promoting regional cooperation and integration. Norms and ideas pertinent to East Asia will likely have a critical influence on the evolution of regional cooperation. In East Asia, the formation of a supranational agency, which was a key factor in Europe's successful integration, is not thinkable for the time being. In this context, taking advantage of specific norms and idcas will be critical in leading to successful regional coupcration.

\section{REFFRENCFS}

Acharya, Amitav, 1997. Ideas, Identity, and Institution-Building: From the 'ASEAN' Way' to the 'Asia-Pacific Way'? Pacific Review 10(3): 329-33.

1998. Culture, Security, Multilateralism: The 'ASEAN Way' and

Regional Order. In Culture and Security: Multilateralism, Ami Control, and Security: Building, ed. Keith R. Krause. Portland, OR: Irank Cass.

Akrasanee, Narongchai and David Stifel. 1992. The Political bconomy of the ASEAN Free Trade Area. In AFTA: The Way Abead, eds. Pearl Imada and Seiji Naya. Singapore: ASEAN Economic Research Unit, Institure of Southeast $\Lambda$ sian Studies. Beeson, Mark. 2002. ASEAN: The challenges of Organisational Reinvention. In Reconfiguring East Asia: Regional Inititutions and Organizations after the Crisis, ed. Mark Becson. London: Routledge Curzon.

Bowles, Paul. 1997. ASEAN, AFTA and 'New Regionalism'. Pacific Affairs 70(2): 219-33.

Chia, Siow Yue. 1998. The ASEAN Frec Trade Area. The Patific Reziew 11(2): $213-32$.

Dunne, Tim. 1995. The Social Construction of International Society. Lumipeun Journal of International Relations 1.(3): 367-89.

Gilprin, Rohert. 1987. The Political Eornomy of International Relations. Princeton, N.J.: 
Princeton IIniversity Press.

Haggard, Stcphan. 1991. Structuraliss and Irs Critics: Recent Progress in International Relations Theory. In Progress in Postuar Intemational Rulations, ads. Emanuel Adler and Beverly Crawtord. New York: Columbia IIniversity Press.

Hasenclever, Andreas, Peter Mayer, and Volker Ritrberger. 199?. Thurries of International Regimes. Cambridge: Cambridge University Pross.

Hernandez, Carolina G. 2001. Challenges for Socicty and Politics. In Reinventing ASEAX, eds. Simon S. C. Tay, Jesus P. Estanislao, and Hadi Soesastro. Singaporc: Institute of Southedst Asian Studies.

Hew, Denis and Hadi Socsastro. 2003. Realizing the $\triangle S E A N$ Economic Community by 2020: ISEAS and ASEAN-ISIS Approaches. ASEAN Eomomit Bullotin 20(3): $292-96$.

Hund, Markus. 2002. From Ncighbourhood Watch (iroup to Commenty? Australicut Jomral of Intemational Affairs $56(1)$ : 99-122.

Hurrell, Andrew, 1995. Regionalism in theoretical perspcotive. In Regionalism in Wonld Politics: Regional Orgunization and International Order, eds. Louise Fawcett. and Andrew Hurrell. New Yurk: Oxford Lniversity Press.

Kehler, Miles. 2000). Legalization as Strategy: The Asia-Pacific Case. Intematirnal Organiation 54(3): 549-71.

Lake, David A. 1988. Poner, Protetion, and Fret Trade: International Samries of US. Comminal Strateg; $7887-1939$. Ithaca, N.Y.: Cornell University Press.

Lim, Linda Y. C. 1996. AST:ANi: Now Modes of Economic Cooperation. In Sintheast

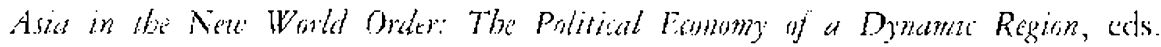
David Wurfel and Bruce Burton. Basingstoke, Hampshire: Macmillan.

l.iu, Fu-Kuo. 2003. East Asian Reyionalism: Theorerisal Perspecrives. In Regionalism in East Asia: Paradigni Shifting?, eds. Fu-Kuo Liu and Philippe Regnier. I.ondon: Routledge Curzon.

Maruya, Toyojiro and H. Abe. 2002. Chugoku no Sangyo Hatten to Kaigai Chokusetsu Toshi Industrial Development in China and Foreign Direct levestment]. In Higashi Ajaa Kokuiai Bumbyi to Chugakn [Internutional Division of Labour in Last Asta and Chinit, eds. Fukunari Kinura, Ioyojiro Maruya and Koichi Ishikawa. Tokyo: JE:TRO.

Moraxcsik, Andrew. 1999. Is Something Rotten in the Srate of Denmark? Constructivism and European Integration. Jonmal of Emrogean Poling 6(14): 669-81. Mutolr, Akihiro. I997. Al'JA no Igi [Implications of AFTA]. Kokusa Seijt 116 (Octoter): $3 ?-45$.

Nagai, Fumio. 2002. Thailand's Trade Policy: WTO Plus FTA? IDE APEC Stidy Centir. Working Paper Series (1/02-No.6.

Nesadurai, Helen E. S. 2003. Globalisation, Domestic Politici and Regionalism: The ASEAN Free Trade Area. london: Routledge.

2001. Explatiang Regionalism in Southeast Asia: Reproducing the Neoliberal Hegemony or Finbedding the Regional Marker. Paper presented at 
the Pan-European Intermational Relations Conference, Netherlands Conference Centre, the Hague, September 9-11.

Powell, Robert. 1994. Anarchy in International Redations Theory: The NeorealistNeoliberal Debate. Intemational Organization $48(2)$ : $313-34$.

Rajan, Ramikishen S. and Rahu Sen. 2002. International Trade in Services in Selected ASEAN Countries: Telccommunications and Finance. Instituic of Southecist Asian Stidies, Economics and Finance 3 (August).

Ravenhill, John. 1995. Economic Cooperation in Southeast Asia: Changing Incentives. Asian Survey 35(9): $850-66$.

Sato. Koichi. 2003. ASEAN Rigimu: ASEAN ni oken Kaigi Gaikn no Hatten to Katai [ASEAN Regime: 'The Development and Problems of Consultation Diplomacy in ASTAN]. Tokio: Keiso shobo.

Stephenson, Sherry and Deunden Nikomborirak. 2001. Iiberalization of Trade in Services: East Asia and the Western Hemisphere. Paper presented at PECC Trade Forum, Regional Trading Arrangements: Stockrake and Next Steps, Bangkok, June 12-13.

Stubbs, Richard. 2000. ASEAN' Plus 'Three: Emerging East Asian Regionalism? Aian Sumey 42(3): 1 140-55.

Thambipillai, Puslipa and Johan Saravanmuttu. 1985. ASEAN Negotiations: Tus insights. Singapore: Institute of Southeast $A$ sian Studies.

'The Joint Meadia Statement. 2003. The Thirty-Fitth ASEAN Fconomic Ministers Mceting, Sepromler, Phnom Pcti l, Cambodia. Available: hetp:/Wwwaseansec. org/15065.htm

INNCTAD. 2001. Wowld Investment Repont 2004: The Sbift towirds Serwies. United Nations Conference on $\Gamma$ rade and Investment.

Wendt, Alexander. 1992. Collective Idontity Formation and the International States.

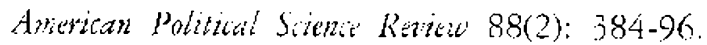

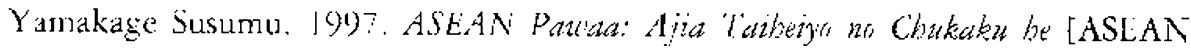
Power: Toward a Center of the Asia-Pacific]. Tokyo: Tokyo Daigaku Shuppankai.

\section{ENDNOTES}

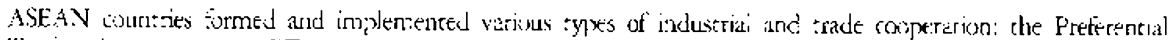

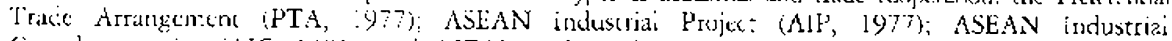

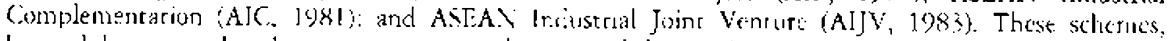
by ind large. protuced meager courcomes because at averse inceresis arrong the rouncrics.

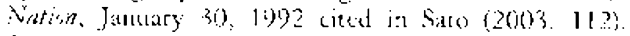

Siran: Times, January 28,1992 cied in Kuwles (399?, 224.

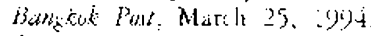

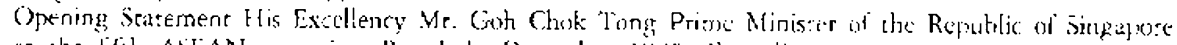

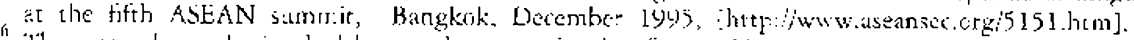

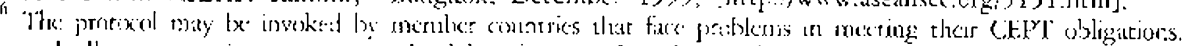

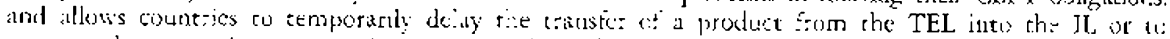

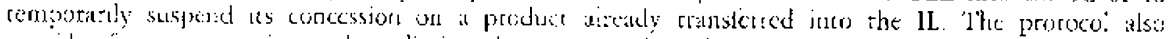

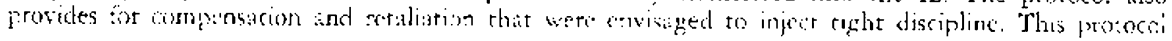


was cunsidered widh Articte 28 of CAALT 1991, and provided a transparent process for countries to mudify their concess:on with compensation under a systcm o: checks and balances.

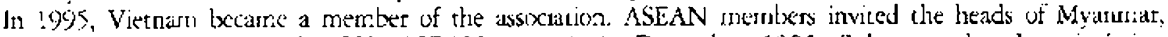
Cambocia, and Lass to the fifel ASEAX sumic in December 1995. Subsequently, the acmission of Myanmar anc: Laos was formally agreed at an ASEAN Foreign Ministers' meeting in May 1997, and they became ofirial membets two months later. Camberials accission was deferred until 1999 dus to the countrys troublesome rapturous domestic affairs.

* The initial number of projects in the Work Plan was forty-cight. As of May 2005, onc-hundred projects wese at various stages of implementation. Funding was securcit fa: eighry projects (80\%), of which forty-fout projects were compictc. twenty-one projects were implemented; fifteen projects secured fitm funding and in the danning seagc. "IAJ Work Plan for the CLMV Countrics: Progress Rejorr as at 15 May 2004," [htep://www. 2scansec.org/pdf/IAl-Article.odf].

ASEAN Amuai Report 2003-2004́, 17.

${ }^{1.1}$ The AEC is one of three piliars that make up the ASEAN Community, as declared by ASEAN leaders in the Bali Concord II. The concore was an accord agreed upon as the niatl summit in October

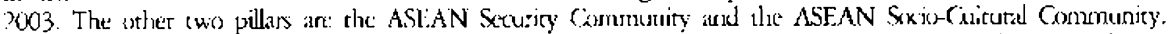
The Bali Cuncord II was the new ASEAN vision, wwenty-sever ycars after the first Bali Concord was signed by the then ASP $\Lambda$ X゙-5.

i Arrording to Hew and Sxesist:0 (2003), ISEAS suggested the "FTA-plus approach," while the ASFAN-ISIS ptoposed a "common market minus approact." Aithough both research institutcs tecommended the

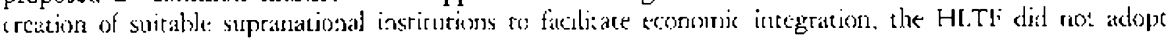
this idea.

"The rleven priotity sectors are as follows: 1) dutonotives: 2) wood-based products; 3) rubber-based products; 4) texciles anc apparels; 5) agro hased produces; 6) fisheries; 7) electronics; 8j ais travel; 9) tourism; 10: e-ASEA.N; and 11) healnaca.

Whe Hanoi Plar of Acion, launched in Decomber 1998, was tie fitst of several acrion plases designed co realize the givals of the ASEAN Vision 2020.

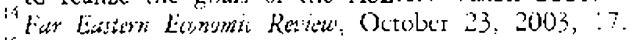

"The Niation, October, 8. 2003.

"Far Eartem Barnomi Reriew. Ocuber, 23. 2003, 6.

?'the Joint Modia Setanent, the: Thirty Fifth ASEAN Rcomonic Ministers Mecting, September 2003, Plonom Penh, Cambodia, [hetp:iwwascansecorg:15065.htm]. 